DOI: $10.28934 /$ jwee18.34.pp60-72

JEL: G21, J16, B54

ORIGINAL SCIENTIFIC PAPER

\title{
Women Entrepreneurship in Serbia - Potentials and Constraints
}

\author{
Olivera Jovanović ${ }^{1}$ \\ Institute of Economic Sciences, Belgrade, Serbia \\ Milena Lazić ${ }^{2}$ \\ Belgrade Banking Academy, Belgrade, Serbia
}

\begin{abstract}
A B S T R A C T
In today's modern society, entrepreneurship is considered to be the driver of economic and social development and the important source of competitive advantage. With that regard and taking into account the empirically proven positive relationship between the gender equality and the level of sustainable economic and social development, the subject of this paper is the assessment of the position of women entrepreneurs in Serbia. The main objective is to identify business and environmental barriers with which female entrepreneurs are confronted. The results of conducted research suggest that there exists a huge potential for the development of women entrepreneurship in Serbia. The women entrepreneurs in Serbia are confronted to significant barriers in their everyday business activities especially taking into account the difficulties in accessing the necessary information about potential markets and technology and even the potential sources for their financing. At the same time they are facing with family care activities and other social norms within the community in which they live. The results are useable for creating supportive and encouraging environment for entrepreneurship in Serbia, especially for women-owned enterprises during business development.
\end{abstract}

\footnotetext{
${ }^{1}$ Address: 12 Zmaj Jovina Str, e-mail: olivera.jovanovic@ien.bg.ac.rs

${ }^{2}$ Address: 12 Zmaj Jovina Str, e-mail: milena.lazic@bba.edu.rs
} 
KEY WORDS: women entrepreneurship, gender equality, financial performances, business barriers, competitiveness, Serbia

\section{Introduction}

In today's modern society, entrepreneurship is considered to be the driver of economic and social development and the important source of competitive advantage. Due to its characteristics, easy adaptation to market changes, adoption of modern trends and creation of jobs in structural changes of economy, entrepreneurship is identified as very important factor of the equal regional development of transition countries. Also, well-being of society is achieved through reducing unemployment rate and regional differences.

Globalization, internationalization and current technological progress are features of todays' environment. They create significant changes in the modern business activities (Vukmirović, 2005). The competitiveness of enterprises in high competitive markets can be improved applying new technology into their business. Entrepreneurs, together with small and medium enterprises have difficulties in business improvement due to luck of financial funds. This factor is considered to be major barrier for their higher competitiveness even if they have good product quality or interesting business ideas (Đuričin, Pantić, 2015). Modern business environment also includes intensively cooperation between countries so the degree of internationalization is increasing in last decades. Chronically poor competitiveness of Serbian market during the global economic crisis has become a basic weakness of Serbian economy (Domazet, Stošić, 2013). However, governmental institutional support is very important for export activities, not only for large companies but also for small and medium entities and entrepreneurs. Parallel with these trends, changes in entrepreneurship are noticed in almost all developing countries. The most significant one is increasing in total share of women in domestic and international entrepreneurship. Those changes are become very important in last ten years. Women's entrepreneurship is factor for the development of overall transitional economies, together with small and medium enterprises sector. It can lead to the reduction of unemployment, the establishment of businesses in new spheres, the implementation of new technologies and the development of entrepreneurship sector. Women's entrepreneurship is also important for real GDP growth, decreasing of unemployment rates, regional and rural development, important for all transition and developing countries which also includes Re- 
public of Serbia. This paper examines characteristics of this kind of business entities in Serbia, their motivation for business and obstacles that they are facing with. The main objective of this paper is to identify business and environmental barriers which female entrepreneurs are confronted with. Also, one of the aims is to provide information about programs of institutional support which will be useful for them.

Taking into account the empirically proven positive relationship between the gender equality and the level of sustainable economic and social development, the subject of this paper is the assessment of the position of women entrepreneurs in Serbia.

\section{Women Entrepreneurship in Serbia- Literature Review}

Besides the contribution to the economic development, the importance of women entrepreneurship is also reflected in numerous researches carried out in recent years in the Southeast Europe region (SEE countries) as well as in Republic of Serbia. The aims and the topics varies across surveys, but the objects for most of them are similar- researchers were interested in identifying women entrepreneurship advantages over other types of organizations, as well as in their potentials and opportunities for further development and contribution to the national economy.

Because Serbia is a SEE country where agriculture is one of the leading sectors in contribution to the economic growth (measured by increase in real GDP), special attention is dedicated to the development of entrepreneurship in this field of the national economy. Particularly interesting is the position of women in overall society, especially in the countryside and in the less development regions of Serbia, which is in line with the hypothesis about importance of female entrepreneurship in balancing between different regional developments. Those types of entities are also significant for improving of women positions in society, especially in business.

Cvijanović at al. conduct a survey analysis during 2010 about the possibilities of launching female agribusiness among women in rural areas in Serbia. Results showed that interest for developing agribusiness entrepreneurship existed, not only for women who are unemployed but also for those one who already have jobs, mainly related to agriculture. Most of them were willing to continue to further education about start up activities and take advices about specific issues in agribusiness, because their knowledge about agribusiness and entrepreneurship were very low. 
Also, one of the several interesting research in Serbia conducted in last decade is designed by Maksimović at al. during 2014 and 2015. Survey results showed the connection between economic development, gender equality and rural development. Republic of Serbia has significant disproportion between the degrees of rural area development and most of women is not related to agribusiness activities. Their jobs are identified as unofficial even if they have own farms, because payments are not official registered at the Statistical Office. Another problem in agrarian sector is manly related to impact of tradition and educational structure between inhabitants in the rural area. Women want to start their own business but they need governmental support in education programs, business development as well as promotion and marketing. Agriculture is important sector for national economy, organizing of organic production is activity which leads to high profits and high export activities and it is convenient for women who want to start their own business (Jovanović at al., 2018).

Special attention in researches among SEE countries is dedicated to financing entrepreneurship and small and medium enterprises through governmental and nongovernmental programs. From 2010, policy makers in Republic of Serbia implement "Programs to support the development of entrepreneurs and SMEs in the Republic of Serbia". 2016 was "Year of Entrepreneurship" which conducted several very important programs for development women entrepreneurs. Scientific paper by Đuričin and Pantić in 2015 investigated factors for the development of micro-financing due to specific characteristics of women's entrepreneurship in Serbia. One of the conclusions is about hypothesis confirmation due to opening 97,000 new jobs for women if micro-financing support is intensively increasing.

Table 1: The impact of microcredits on the growth of women's employment

\begin{tabular}{llllll}
\hline Year & $\mathbf{2 0 1 3}$ & $\mathbf{2 0 1 4}$ & $\mathbf{2 0 1 5}$ & $\mathbf{2 0 1 6}$ & $\mathbf{2 0 1 7}$ \\
\hline Female & 978.107 & 994.107 & 1.016 .107 & 1.043 .107 & 1.074 .107 \\
New female jobs & & 16.000 & 22.000 & 27.000 & 31.000 \\
\hline
\end{tabular}

Source: Đurićin, Pantić, JWEE, vol 2015, no 1-2, 50-66

Balaban et al. suggest that the financial sector has very important role for the development of entrepreneurship, pointing to the different possibilities of cheaper funding development of guidelines for small and medium enterprises, but in other hand in some cases financial sector has negative 
impact for growing through expensive sources of financing of development (Balaban et al, 2016).

Innovations have become not only an important determinant of a company's successful development but also their requirement. Innovative enterprises can be considered as the key driver of competitiveness, increased productivity, employment and overall economic development (Prljić et al., 2016).

According survey which was conduct in 2014 (Pantić, 2014), innovations leads to increase in prosperity of community. Entrepreneur innovations can increase their net profit (profit after taxes) and share in the national market. Compared to other kind of entities, entrepreneurs can be faster in implementing of innovation but the luck of financial funds (and very often the luck of knowledge) can be obstacles for their competitiveness. Results in the study „Women entrepreneurship in Serbia, 2012“ show that the business started by women is generally smaller in compare to business started by men in all low and middle income countries. Women are facing with difficulties like credit access, market information, potentials market access in business activities so implementing of innovation is not so fast compared to business leading by men. At the same time, women taking into account care for families and facing with social norms within the community in which they live. But, apart from the role in stimulating the growth of economic development, the private sector (together with entrepreneurs) contributes to creating new jobs and improving living standards. Therefore, it is absolutely necessary to engage women in business activities, because benefits from ideas and potentials that women can bring to the labor market are huge.

\section{Methodology}

This section contains general description of methodological approach used in this paper. In order to adequately analyze the position of women entrepreneurs in Serbia, specifically focusing on the conditions of business environment and barriers to doing business, in addition to standard desk research method and the analysis and comparison of secondary data, the case study method was also conducted. Consequently, combination of qualitative and quantitative research techniques was used in order to provide more comprehensive research results.

With that regard, five in-depth interviews with selected women entrepreneurs in Serbia were conveyed in period March - May 2018. The sample 
was constructed in accordance to ranking list provided by the Association of Business Women of Serbia (http://poslovnezene.org.rs) where top ten women entrepreneurs in Serbia for 2017 were listed.

The main tool used in the survey was questionnaire specially designed in accordance with the aim and the objectives of the research. Regarding that, the questionnaire used for the purpose of this survey was semi structured and consisted of three parts. Within the first group of questions, general information about level of education and basic characteristics of the company owned by women entrepreneurs in Serbia has been collected. The second group of questions was conceived to provide an insight into the business performances of these companies, while the third group of questions dealt with the analysis of the barriers which women entrepreneurs in Serbia were facing in their everyday business.

Before the start of the survey, the questionnaire was sent to the group of selected researchers of the Institute of the Economic Sciences in Belgrade to ensure the logical sequence of the questions as well as the clarity of each question. After that, the questionnaire was redesigned in accordance with the inputs obtained. This method aimed to improve the quality of data generated as well as to avoid potential defects within the survey.

In-depth interviews present useful method to collect rich, descriptive data about people's behaviors, attitudes and perceptions. Face-to-face method allows the reading of body language for the purpose of adding higher level of understanding the answer of the respondents.

Finally, the data collected was coded and analyzed using SPSS, statistical software specially designed for the purpose of social sciences surveys. The research analyses used in this paper were predominantly based on descriptive statistics using cross tabulation techniques.

\section{The Survey Results}

This part of the study provides quantitative results of the case study analysis conducted with five most successful women entrepreneurs in Serbia according to the ranking list provided by the Association of Business Women in Serbia.

The section is divided into three parts. The first part consists of general information about women entrepreneurs which were involved in the research. The second part contains data related to the business performances of the company owned by women entrepreneurs in Serbia, while in the third 
part the basic obstacles that these women face in their everyday business activities are listed.

The majority of the respondents $(60 \%)$ reported financial gain as the main motive for starting their own business, which was followed by unwillingness to work for others (20\%) and unemployment (20\%) with the same frequency (Figure 1). The reported results correspond to other surveys which conclude that the most female entrepreneurs in developing economies are motivated to start their business out of necessity, reflect lack of employment alternatives or dissatisfaction with existing employment (RadovićMarković, Achakpa, 2018).

Figure 1: The main motivation for starting the business

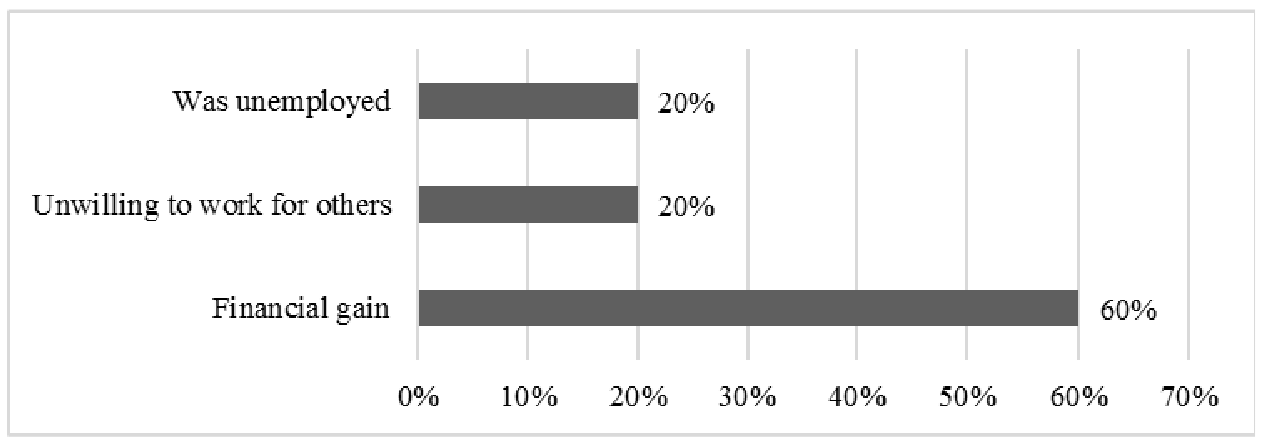

Source: Authors' autonomous work based on data obtained through conducted in-depth interviews

Figure 2: The source of start-up capital

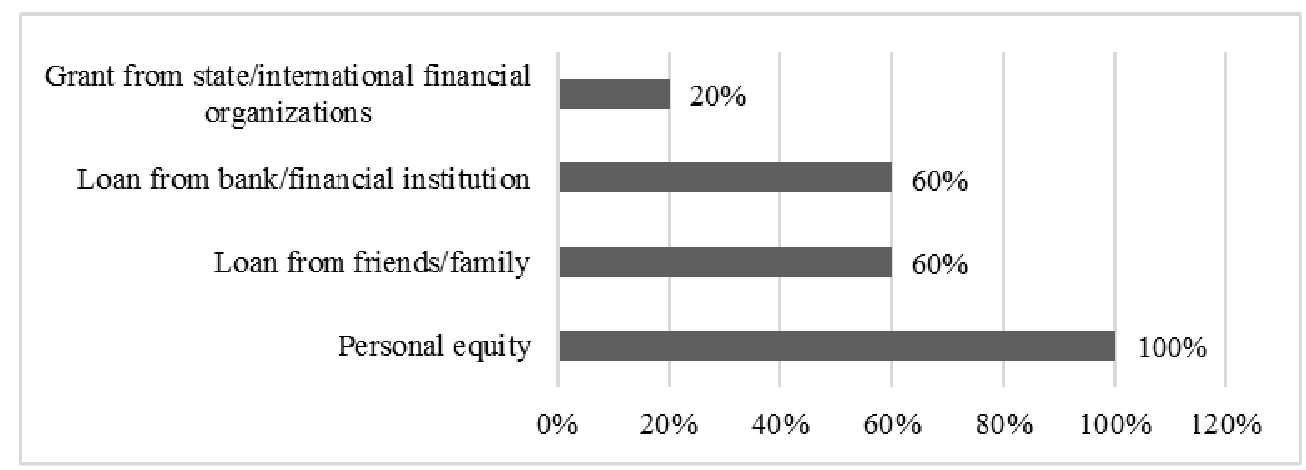

Source: Authors' autonomous work based on data obtained through conducted in-depth interviews 
In order to start their own business, all of the respondents conveyed by the research used their own, private capital; a large number of them (60\%) also used loans from friends and families, as well as bank loans. Distribution of respondents' answers to this question is shown in Figure 2.

Furthermore, the structure of borrowed capital of women entrepreneurs in Serbia implied their dominant financing by banks, followed by relatives and friends. In addition, grants from the state / international financial organizations have also been used in business financing, but to a much lesser extent due to complicated administrative procedures.

When it comes to innovations, all of the respondents considered that introducing innovations into business is of crucial importance when it comes to the increase of market share of the company. In other words around, business innovations were assessed to be the engine of further growth and development of the company.

With that regard, in Figure 3 it is presented that $60 \%$ of respondents have been introducing innovations into their business processes periodically, while $40 \%$ do that on continuous basis. Innovation for women in enterprises can be found in aftermarket services, which can be especially interesting in the domestic market (Domazet et al. 2018).

Figure 3: Introduction of innovation into business processes

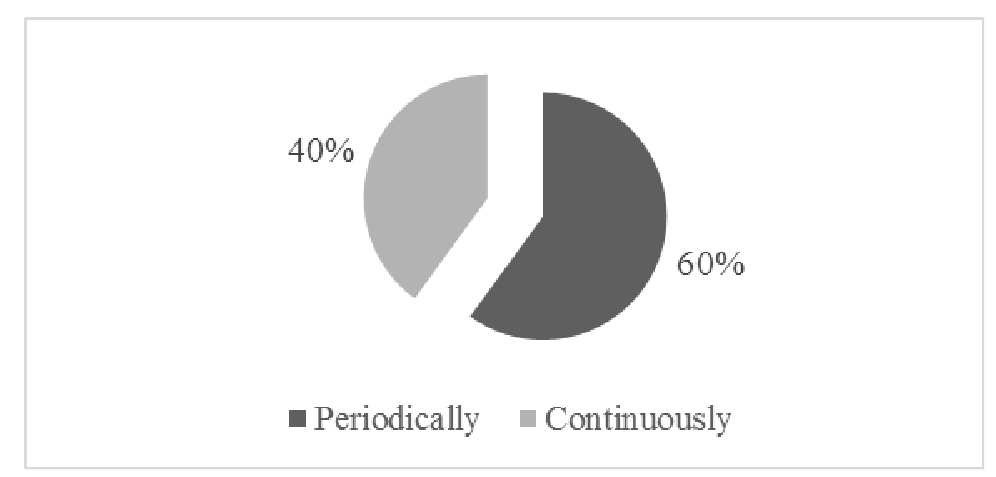

Source: Authors' autonomous work based on data obtained through conducted in-depth interviews

When it comes to business performances, interestingly all of the surveyed women entrepreneurs in Serbia have stated that their sales level have increased in comparison to previous year approximately in the range from 10 to $20 \%$. According to the respondents' answers, this is a result of in- 
creased investment in promotional activities, employees training programs, as well as stronger state support for the development of women entrepreneurship in Serbia in the past few years (Figure 4).

Figure 4. Three main reasons for better business performances in current period

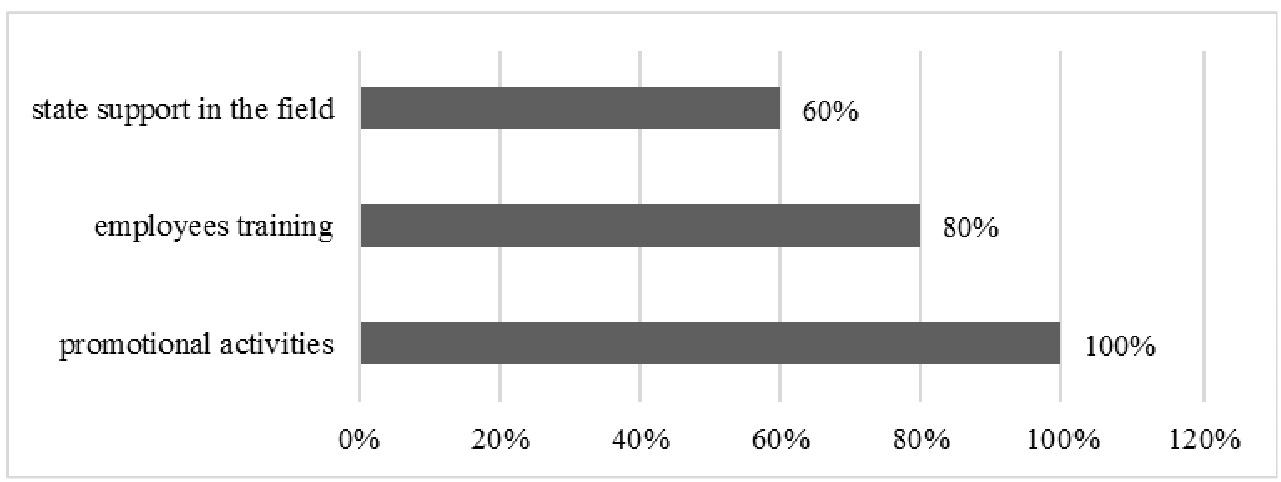

Source: Authors' autonomous work based on data obtained through conducted in-depth interviews

All respondents claimed that they were offering their clients the possibility of deferred payment. $60 \%$ of them stated that the deadline for deferred payment amounts to 30 days, while the remaining $40 \%$ led to the deadline for deferred payment of up to 60 days.

Figure 5: Deferred payment options for clients

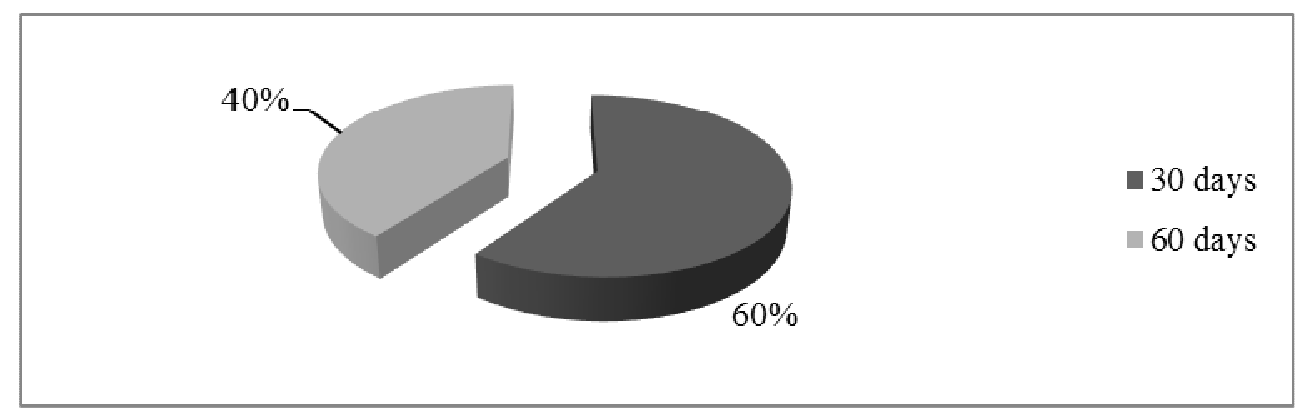

Source: Authors' autonomous work based on data obtained through conducted in-depth interviews 
When it comes to the barriers that women entrepreneurs in Serbia face in their everyday business, the following answers have been most commonly highlighted (Figure 6):

- Lack of information (60\%)

- Unfair competition (60\%)

- Negative attitudes of the environment towards women entrepreneurs $(20 \%)$

- Difficult access to finance (20\%)

- Lack of support from the family (20\%)

Figure 6: Barriers that women entrepreneurs in Serbia continuously face in their business

- lack of information

- unfair competition

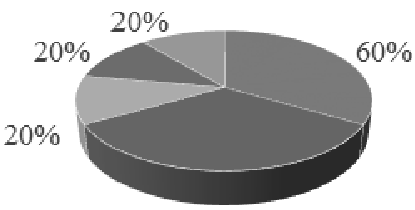

- negative attitude of the environment towards women entrepreneurs

- difficult access to finance

- lack of support from the family

Source: Authors' autonomous work based on data obtained through conducted in-depth interviews

In the end, main observations of surveyed five out of ten most successful women entrepreneurs in Serbia upon current issues in the field are listed:

- $80 \%$ of respondents believe that the position of women entrepreneurs in Serbia is not at a satisfactory level and that there is a great potential for improving the position of women entrepreneurs in business.

- Only 20\% of the respondents consider that the business environment in Serbia is suitable for the implementation and development of women's entrepreneurship.

- Most of the surveyed women entrepreneurs believe that significant development programs for women entrepreneurship have emerged in the last five years in the form of incentive financial resources, 
possibilities for using subsidies, more favorable borrowing from banks, organizing events for connecting entrepreneurs and sharing experiences.

- Almost all of the respondents agreed with the view that fairs / conferences / organized gatherings etc. represent very important factors for improving the business performances. On the other hand, despite that conclusion they are not able to attend such meetings frequently due to their family obligations.

\section{Key Findings}

All research with the topic of entrepreneurship over the years conducted in Serbia over the years, confirmed the importance of women entrepreneurship for the development of the economy and for improving the position of women in society. This research provides a detailed insight into women entrepreneurs in Serbia through analyzes of depth interviews of several entities in the ownership of women. While the findings also provide an interesting conception of the current status of the company in the ownership of women, the report also includes advice for future research on the topic. One of the main goals of this report is the construction of support to policy makers that will stimulate a developing environment for women entrepreneurship in Serbia. Results can help in creating good policies for increasing the share of women in business.

According the fact that access to external sources of financing has been identified as barrier for development, the authors of this paper believes that this segment needs to be improved in the future. In the forthcoming period it is necessary to create new mechanisms of financial support in order to make financial resources available to women entrepreneurs. One of the recommendations should be creating environment for establishing private investment funds as well as improving banking sector in providing financial services to women entrepreneurs.

\section{Conclusion}

Besides standard desk research method and the analysis and comparison of secondary data, the survey method interview was conducted with the aim of collecting additional information. The questionnaire used for the purposes of this research consists of three parts. Within the first group of 
questions, general information about the level of education and basic characteristics of the company owned by women entrepreneurs in Serbia has been collected. The second group of questions was conceived to provide an insight into the business performances of these companies, while the third group dealt with the analysis of the barriers which women entrepreneurs in Serbia were facing in their everyday business.

The results of conducted research suggest that there exists a huge potential for the development of women entrepreneurship in Serbia. The women entrepreneurs in Serbia are confronted to significant barriers in their everyday business activities especially taking into account the difficulties in accessing the necessary information about potential markets and technology and even the potential sources for their financing. At the same time they are facing with family care activities and other social norms within the community in which they live.

\section{Acknowledgements}

This paper is a result of research projects under the codes 179015 (Challenges and prospects of structural changes in Serbia: Strategic Directions for Economic Development and harmonization with EU requirements), and 31005 (Modern Biotechnological Approach to Solving the Problem of Drought in Agriculture of Serbia) financed by the Ministry of Science and Technological Development of the Republic of Serbia

\section{References}

[1] Babović, M. 2012. Polazna studija o preduzetništvu žena u Srbiji. Beograd, Program Ujedinjenih nacija za razvoj.

[2] Balaban M., Župljanin S., Ivanović P. 2016. Source of Finance for Entrepreneurship Development. Economic Analysis, vol. 49, no 1-2, Institute of Economic Sciences, Belgrade. pp. 48-58

[3] Cvijanović J. i saradnici. 2011. "Istraživanje zainteresovanosti žena za preduzetništvo u agrobiznisu”, Ekonomika poljoprivrede, godina 58, br. 1, str. 67

[4] Domazet, I., Stošić, I. 2013. "Strengthening the competitiveness of Serbian economy and the corporate market restructuring", Economic Analysis, Vol. 46, No 3-4, pp. 108-124. 
[5] Domazet, I., Stošić, I., Lazić M. 2018. "Competitive Relations in the Aftersales Market of Major Home Appliances in Serbia", Economic Analysis, Vol. 51, No 1/2, pp. 47-59.

[6] Vukmirović N. 2005. "Modeli podrška razvoju preduzetništva", Industrija, 4/2005, str. 1-18

[7] Đuričin S, Pantić O. 2015. "The development of Micro crediting as a factor of promoting women entrepreneurship in Serbia", Journal of Women's Entrepreneurship and Education, no. 1-2, pp.50-55

[8] Jovanović O., Lazarević Moravčević M., Đuričin S. 2018. “Organska poljoprivreda u funkciji održivog razvoja Srbije, Ecologica, 25(91), pp. 722726.

[9] Maksimović G., Otović S., Demirović D., Vermezović T. 2016. "A review investigating agrarian female entrepreneurship in the Republic of Serbia", Ekonomika poljoprivrede, godina 63, br. 1, str. 29-46

[10] Pantić O. 2015. Uloga sektora MSPP u strukturnim promenama poljoprivrede Republike Srbije, Strukturne promene u Srbiji - dosadašnji rezultati i perspektive. Institut ekonomskih nauka, Beograd, pp. 331-345

[11] Prljić K., Mijalković J., Prljić S. 2016. Innovation Analysis of the sector of Small and Medium Enterprises and Entrepreneurs (SMEs) in the Republic of Serbia. Economic Analysis, vol. 49, no 3-4, Institute of Economic Sciences, Belgrade. pp. 81-96

[12] Radović-Marković M., Achakpa P. 2018. Employment Woman Through Entrepreneurship Development and Education in Developing Countries. Journal of Women Entrepreneurship and Education (JWEE), no. 1-2/2018, Institute of Economic Sciences, Belgrade. pp. 17-30

[13] “Žensko preduzetništvo - Analiza poslovanja na Kosovu”, 2017. Rinvest Institute, Priština u saradnji sa USAID.

Article history: $\quad$ Received: 24 November, 2018

Accepted: 3 December, 2018 